\title{
Vulvar wart in a child
}

\section{Selma El Kadiri', Hanane Bay Bay ${ }^{1}$, Rhizlane Chaoui', Zakia Douhi', Sara Elloudi', Fatima Zahra Mernissi ${ }^{1}$, Nawal Hammas ${ }^{2}$, Layla Tahiri Elousrouti ${ }^{2}$, Hind El Fatemi ${ }^{2}$, Laila Chbani² $^{2}$}

\author{
${ }^{1}$ Department of Dermatology, Hassan II University Hospital, Fez, Morocco, ${ }^{2}$ Department of Pathology, Hassan II University \\ Hospital, Fez, Morocco
}

Corresponding author: Selma El Kadiri, MD, E-mail: elkadiri-s@hotmail.com

\begin{abstract}
Human papillomaviruses ( HPV) are commonly associated with mucocutaneous infections in a child. Several HPV types can cause anogenital warts. Their occurrence in childhood should require some consideration and careful examination to mean their transmission. We report a new case of vulvar wart in an 8-year-old child diagnosed initially as hymeneal polyps. Dermatological examination showed a gelatinous and erythematous lesion surrounding the urethral meatus and another violaceus tumor tapioca seeds like in the vulva. Histological examination was compatible with a vulva wart and the detection of viral typing revealed HPV2.
\end{abstract}

Key words: Human papillomaviruses; Anogenital warts; Children

\section{INTRODUCTION}

Human papillomaviruses ( HPV) are commonly associated with mucocutaneous infections in a child [1]. Several HPV types can cause anogenital warts. Their occurrence in childhood should require some consideration and careful examination to mean their transmission [2]. Herein we report a new case of vulvar wart in an 8-year-old child.

\section{CASE REPORT}

An 8-year-old girl diagnosed previously as hymenal polyps presented to our consultation with a painful lesion located on the external genitalia which was noticed recently by her mum. The girl reported occasional bleeding and dysuria. She denied any history of sexual abuse. Physical examination revealed a gelatinous and erythematous lesion surrounding the urethral meatus and another violaceus tumor resembling tapioca seeds under posterior seeds (Figs. la and lb). The rest of the examination didn't show other localization of warts or findings suggestive of abuse. The skin examination of her mother was also normal. She lived with her parents and her young sister. As part of the investigation, her parents were required to be evaluated for evidence of sexually transmitted infections with external exams with no significant findings. We performed an excisional biopsy of the two lesions. Histological examination showed hyperplasic epithelium with parakeratosis, architectural desorganization, atypia and koilocytes (Figs. 2-4). These cells were marked with pl6 and ki67. These findings were compatible with the diagnosis of a vulvar wart. Detection of viral typing in genital lesions revealed HPV2. No recurrence occurred after a one-year follow-up.

\section{DISCUSSION}

Genital warts are infectious disorders resulting from HPV infection. The incubation phase in a variable from months to years. Girls are more frequently affected than boys, at a ratio of 3:1.7 [3]. However, little is known about the epidemiology of the virus in the pediatric population In a cohort of 34 prepubertal children, the

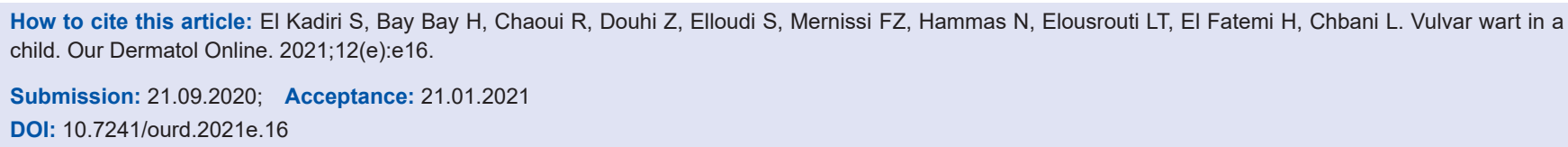




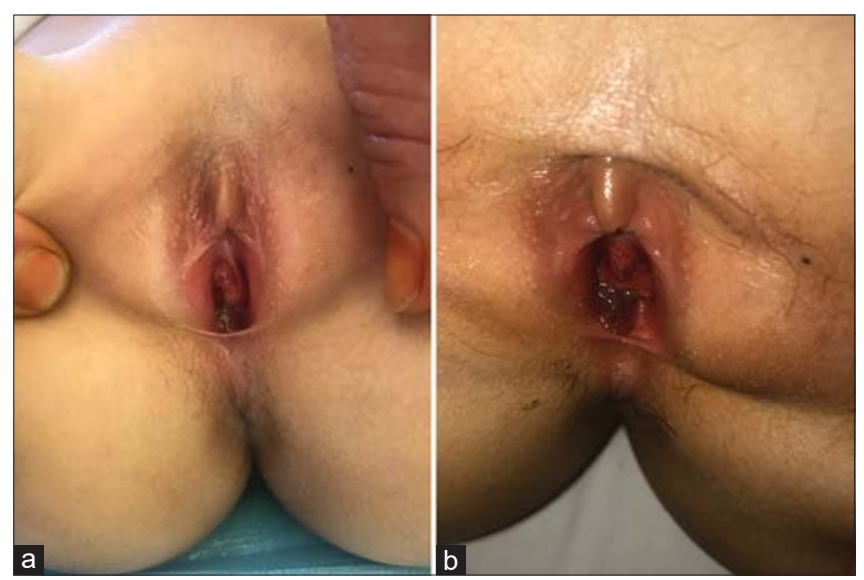

Figure 1: (a) Gelatinous and erythematous lesion surrounding the urethral meatus and another violaceus tumor resembling tapioca seeds under posterior seeds. (b) View from above.

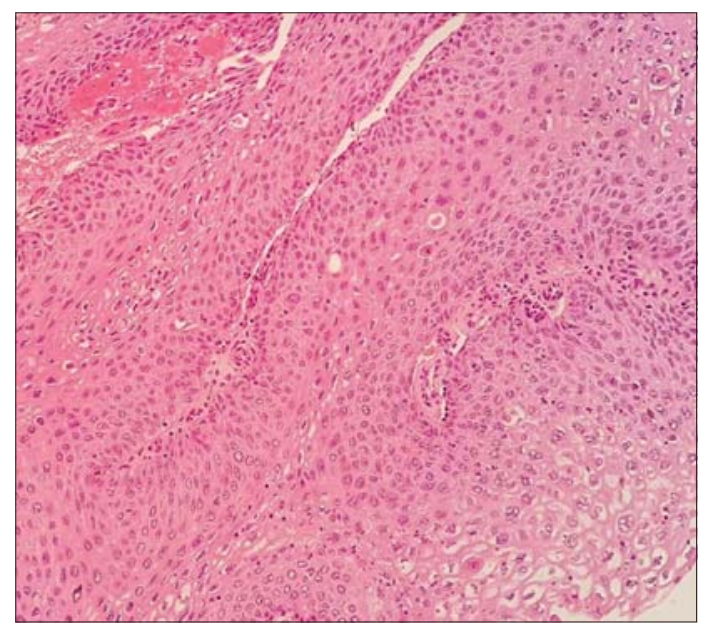

Figure 2: Histological image showing hyperplasic epithelium with numerous koilocytes and architectural disorganization.

perianal localization interested $67,6 \%$ of cases and was the most frequent site [2]. Typing the HPV virus is useful when making a diagnosis and assessing children with genital warts. It is known that HPV type 2 causes hand, foot, and body warts. Although this tropism is not absolute particularly in the pediatric population. They can also be found in the anogenital area [4]. In our patient, we guess that the possible mode of transmission was by autoinoculation. We exclude a transmission by genital penetration because there was no evidence of genital trauma or hymen perforation or history of sexual abuse. The localization of warts in the vulva is characterized by a moist, granulomatous appearance like tapioca pudding. Unlikely, cutaneous lesions are dry, pointed with warty appearance [5]. Studies suggest that lesions should be actively treated if they persist more than 2 years of being symptomatic [6]. We chose surgical excision as a therapeutic approach because she had a few lesions. Other non-

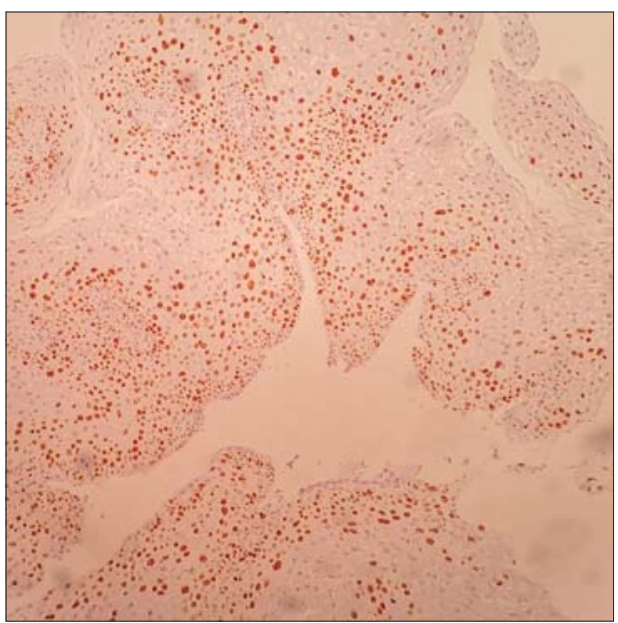

Figure 3: Immunohistochemical study showing positivity for Ki67 (HES $\times 100)$.

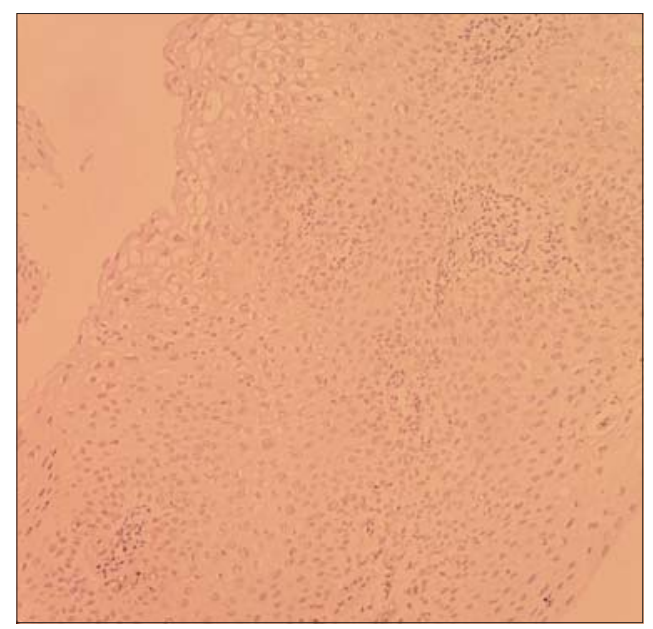

Figure 4: Immunohistochemistry revealing positivity for P16.

surgical methods include cryotherapy, ablative laser therapy, pulsed-light therapy, and electrocoagulation are helpful and efficacious [1]. Imiquimod at 5\% has been approved for a child aged 12 years or older as immunomodulator with less recurrences [7], Drugs with antimitotic properties, including podophyllotoxin, podophyllin, and 5-fluoracyl, are also available for the treatment of vulvar localizations but have not been approved for the pediatric population [8]

\section{CONCLUSION}

Although they are a benign condition, the dermatologist may be the first physician to manage vulvar warts in a child. They are not a diagnostic criterion for sexual abuse. As physicians, we should be aware of signs of abuse, perform the appropriate documentation and testing. 


\section{Consent}

The examination of the patient was conducted according to the principles of the Declaration of Helsinki.

The authors certify that they have obtained all appropriate patient consent forms, in which the patients gave their consent for images and other clinical information to be included in the journal. The patients understand that their names and initials will not be published and due effort will be made to conceal their identity, but that anonymity cannot be guaranteed.

\section{REFERENCES}

1. Costa-Silva M, Fernandes I, Rodrigues AG, Lisboa C. Anogenital warts in pediatric population. An Bras Dermatol. 2017;92:675-81.

2. Costa-Silva M. Azevedo F, Lisboa C. Anogenital warts in children: Analysis of a cohort of 34 prepubertal children. Pediatr Dermatol. 2018;35:e325-7.

3. Culton DA, Morrell DS, Burkhart CN. The Management of Condyloma Acuminata in the Pediatric Population. Pediatr Ann. 2009;38:368-72.

4. Kingston M, Smurthwaite D, Dixon S, White C. How to manage children with anogenital warts. Sex Transm Infect. 2017;93:267-9.

5. Murray PR, Ks Rosenthal, Pfaller MA. Papillomaviruses and Polyomaviruses. In: Murray PR, Ks Rosenthal, Pfaller MA, editors. Medical Microbiology. 7th ed. Philadelphia: Elsevier Sounders; 2013. pp.

6. Richardson H, Kelsall G, Tellier P, Voyer H, Abrahamowicz M, Ferenczy A, et al. The natural history of type-specific human papillomavirus infections in female university students. Cancer Epidemiol Biomarkers Prev. 2003;12:485-90.

7. Markowitz LE, Dunne EF, Saraiya M, Chesson HW, Curtis CR, Gee J, et al. Centers for Disease Control and Prevention (CDC). Human papillomavirus vaccination: recommendations of the Advisory Committee on Immunization Practices (ACIP) MMWR Recomm Rep. 2014;63:1-30.

8. Lacey CJ, Goodall RL, Tennvall GR, Maw R, Kinghorn GR, Fisk PG, et al. Randomised controlled trial and economic evaluation of podophyllotoxin solution, podophyllotoxin cream, and podophyllin in the treatment of genital warts. Sex Transm Infect. 2003;79:270-5.

Copyright by Selma El Kadiri, et al. This is an open access article distributed under the terms of the Creative Commons Attribution License, which permits unrestricted use, distribution, and reproduction in any medium, provided the original author and source are credited.

Source of Support: Nil, Conflict of Interest: None declared. 